Heroine of the

Harlem Renaissance and Beyond 


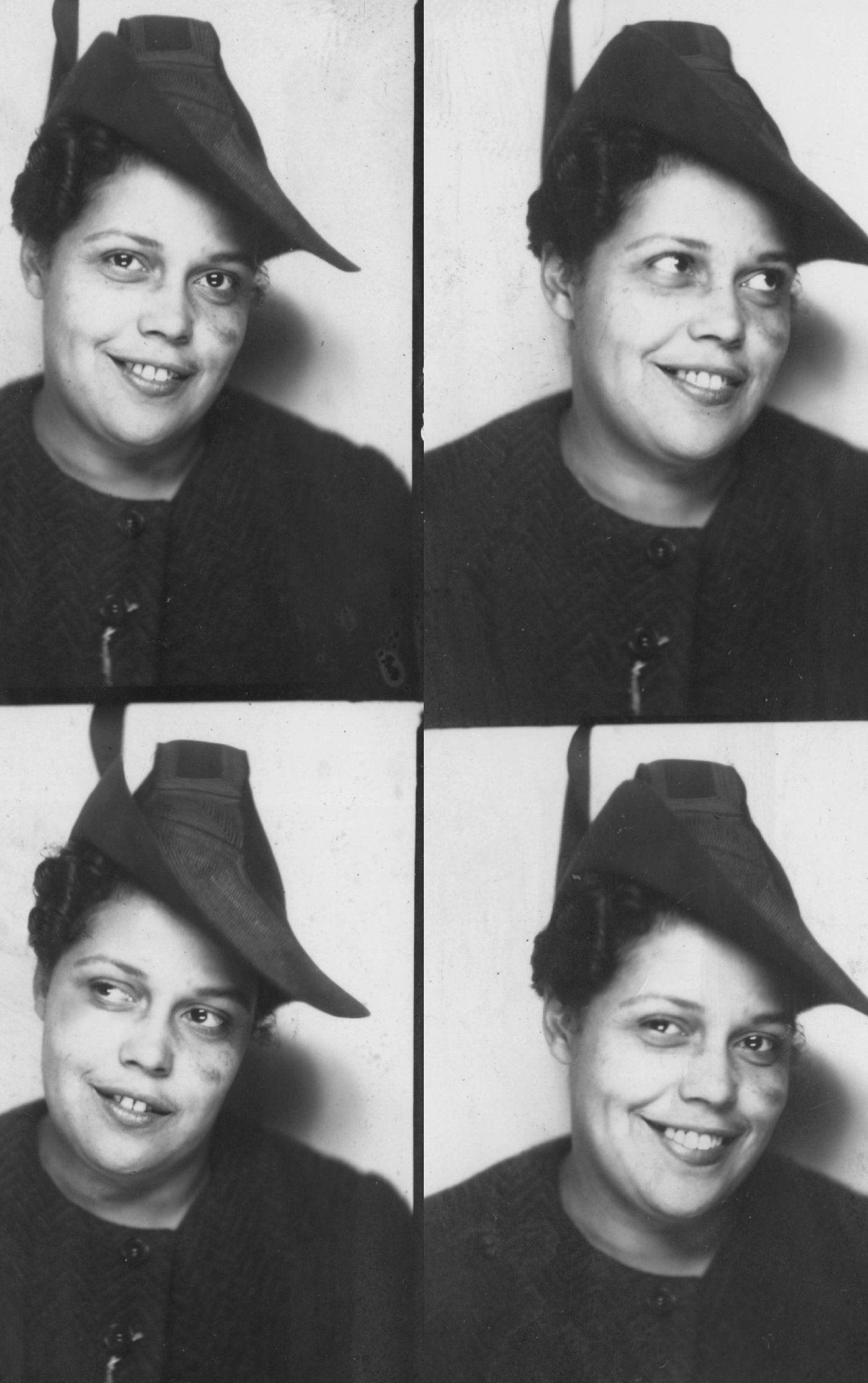




\section{Heroine of the}

Harlem Renaissance

and Beyond

Gwendolyn Bennett's Selected Writings

Edited by Belinda Wheeler

and Louis J. Parascandola

The Pennsylvania State University Press

University Park, Pennsylvania 
Unpublished materials held at the Schomburg Center are ( $\odot$ Schomburg Center for Research in Black Culture, The New York Public Library.

Historical photographs of Gwendolyn Bennett appear courtesy of the Photographs and Prints Division, Schomburg Center for Research in Black Culture, The New York Public Library, Astor, Lenox, and Tilden Foundations.

Frontispiece: Photo booth portraits of artist and writer Gwendolyn Bennett, circa I930s. Photo (C) The New York Public Library.

Untitled [River Landscape] reproduced courtesy of Swann Auction Galleries.

Opportunity cover art reproduced courtesy of the National Urban League, Opportunity: Journal of Negro Life.

The authors thank the Crisis Publishing Co., Inc., the publisher of the magazine of the National Association for the Advancement of Colored People, for the use of the image first published in the March 1924 issue of Crisis.

Library of Congress Cataloging-in-Publication Data

Names: Bennett, Gwendolyn, 1902-198I, author. | Wheeler, Belinda, 1974- editor. | Parascandola, Louis J., I952- editor.

Title: Heroine of the Harlem Renaissance and beyond : Gwendolyn Bennett's selected writings / edited by Belinda Wheeler and Louis J. Parascandola.

Description: University Park, Pennsylvania : The Pennsylvania State University Press, [2018] | Includes bibliographical references and index.
Summary: "Explores the role of writer Gwendolyn Bennett as an important contributor to the Harlem Renaissance. Includes Bennett's published and unpublished poetry, fiction, essays, diaries, letters, and artwork" - Provided by publisher.

Identifiers: LCCN 20I800I477 | ISBN 9780271080963 (cloth : alk. paper) | ISBN 9780271080970 (pbk. : alk. paper)

Subjects: LCSH: Bennett, Gwendolyn, I902198I-Criticism and interpretation. | Harlem Renaissance. | LCGFT: Poetry. | Fiction. | Essays. | Diaries. | Personal correspondence. Classification: LCC PS3503.E5474 A6 2018 | DDC 818/.5209- dc23

LC record available at https://lccn.loc .gov/201800I477

Copyright (C) 2018 The Pennsylvania State University

All rights reserved

Printed in the United States of America Published by The Pennsylvania

State University Press,

University Park, PA I6802-1003

The Pennsylvania State University Press is a member of the Association of University Presses.

It is the policy of The Pennsylvania State University Press to use acid-free paper. Publications on uncoated stock satisfy the minimum requirements of American National Standard for Information Sciences-Permanence of Paper for Printed Library Material, ANSI Z39.48-1992. 